\title{
Chemical composition and in vitro digestibility of fresh sugarcane hydrolysed with calcium oxide (CaO)
}

\section{Composição bromatológica e digestibilidade in vitro da cana-de- açúcar in natura hidrolisada com óxido de cálcio (CaO)}

\author{
Felipe Nogueira Domingues ${ }^{1 *}$; Mauro Dal Secco de Oliveira ${ }^{2}$; \\ Diego Azevedo Mota ${ }^{3}$; Juliana dos Santos ${ }^{4}$; Augusto Sousa Miranda \\ Raimundo Parente de Oliveira ${ }^{6}$
}

\begin{abstract}
The objective was to evaluate the chemical composition and in vitro digestibility of sugarcane hydrolysed with increasing doses of calcium oxide and varying air exposure times. A completely randomised, split plot design was used; the doses were allocated to the plots, and the air exposure times were allocated to the subplots, with four repetitions. The data underwent analysis of variance and were laid out according to the effect of the treatment on the components of polynomial regressions, and evaluated at the 5\% probability. The increase in the dosage negatively affected the quantities of neutral-detergent fibre (NDF), acid-detergent fibre (ADF), lignin (LIG), total carbohydrates (TC), cellulose (CEL), crude protein $(\mathrm{CP})$, and ether extract (EE); and positively affected the quantities of non-fibrous carbohydrates (NFC) and mineral matter (MM). The addition of calcium oxide improved the in vitro digestible dry matter (IVDMD) coefficients and was able to keep up to 72 hours. The in vitro digestibility of the neutral-detergent fibre (IVDNDF) and of the acid-detergent fibre (IVDADF) coefficients decreased when calcium oxide was added. Calcium oxide has the ability to hydrolyse the fibrous fraction and conserve chopped sugarcane. Doses of 0.5 and $1.0 \%$ lime exhibited similar results to those achieved at higher doses; therefore, higher doses are not required in the hydrolyses of sugarcane. Over time, the sugarcane deteriorates, but this deterioration is reduced by the addition of calcium oxide.
\end{abstract}

Key words: Alkali treatment, food analysis, hydrolysing agent, hydrolysis, Saccharum officinarum

\section{Resumo}

Objetivou-se avaliar a composição bromatológica e a digestibilidade in vitro da cana-de-açúcar hidrolisada com doses crescentes de óxido de cálcio e diferentes tempos de exposição ao ar. Utilizouse o delineamento inteiramente casualizado, em esquema de parcelas subdivididas, sendo as doses alocadas nas parcelas e os tempos de exposição ao ar nas subparcelas, com quatro repetições. Os dados foram submetidos à análise de variância e desdobrados quanto ao efeito de tratamento nos componentes de regressões polinomiais, e avaliados a $5 \%$ de probabilidade. A elevação das doses influenciou negativamente os teores de FDN, FDA, LIG, CT, CEL, PB e EE, e positivamente nos teores de CNF e

${ }^{1}$ Prof., Universidade Federal do Pará, UFPA, Faculdade de Medicina Veterinária, Castanhal, PA, Brasil. E-mail: felipend@gmail.com

2 Prof., Universidade Estadual Paulista “Júlio de Mesquita Filho”, UNESP, Jaboticabal, SP, Brasil. E-mail: mauro@fcav.unesp.br

${ }^{3}$ Prof., Universidade Federal da Fronteira Sul, UFFS, Erechim, RS, Brasil. E-mail: diegomota@zootecnista.com.br

${ }^{4}$ Prof $^{\mathrm{a}}$, Instituto Federal do Rio Grande do Sul, IFRS, Campus Sertão, RS, Brasil. E-mail: jusantos1@hotmail.com

5 Discente do Curso de Mestrado do Programa de Pós-Graduação em Ciência Animal, UFPA, Belém, PA, Brasil. E-mail: augusto@ veterinario.med.br

${ }^{6} \mathrm{Eng}^{\mathrm{o}} \mathrm{Agr}^{\mathrm{o}}$, Belém, PA, Brasil. E-mail: rparente47@hotmail.com

* Author for correspondence 
MM. A utilização do aditivo melhorou os coeficientes de DIVMS e foi capaz de manter até 72 horas. Houve decréscimo nos coeficientes de DIVFDN e DIVFDA com a adição de óxido de cálcio. O óxido de cálcio tem capacidade de hidrolisar a fração fibrosa como também conservar a cana-de-açúcar já picada. As doses 0,5 e 1,0\% de cal, apresentaram resultados semelhantes às doses superiores, não havendo necessidade de utilização de doses mais elevadas na hidrolise da cana-de-açúcar. Com o decorrer do tempo ocorre deterioração da cana-de-açúcar, porém esta é menor quando tratada com óxido de cálcio. Palavras-chave: Agente hidrolizante, análise de alimento, hidrólise, Saccharum officinarum, tratamento alcalino

\section{Introduction}

Sugarcane is an important forage crop for cattle feed during the dry season in central Brazil, due to the increased production of this crop and because it has the lowest cost-per-ton of dry matter (DM) and energy. However, sugarcane has reduced fibre digestibility, which decreases the DM consumption and nutrient ingestion (CORREA et al., 2003; CARVALHO et al., 2010).

Traditionally, the use of sugarcane is based on the daily harvest and the immediate supply of fresh forage. However, this management system is also cited as an obstacle for using this forage (PINA et al., 2011). Recently, the use of quicklime $(\mathrm{CaO})$ has been reported for the treatment of sugarcane to maintain the nutritional quality of this forage for several days, thereby eliminating the need for daily harvesting.

The use of calcium oxide allows chopped sugarcane to be stored for at least $72 \mathrm{~h}$ after harvesting, improving the logistics for the use of sugarcane and decreasing the costs related to harvesting and transportation (PINA et al., 2011). This technology can be used on any scale production, seeing that already exist on the market machines that allow performing hydrolysis of sugarcane in large quantities.

The objective of the present study was to evaluate the chemical composition and in vitro digestibility of sugarcane hydrolysed with increased doses of calcium oxide and different air exposure times.

\section{Materials and Methods}

Sugarcane variety IAC 86-2480, was harvested manually at 12 months of age and chopped in a stationary chopper to obtain 8 - to $10-\mathrm{mm}$ pieces. The chopped sugarcane was then placed in piles weighing approximately $15 \mathrm{~kg}$ (fresh matter) and treated with the following doses of calcium oxide: 0 (control), $0.5,1.0,1.5$, and $2.0 \%$, based on the natural material.

For each treatment, the calcium oxide (quicklime) was diluted in $4 \mathrm{~L}$ water per $100 \mathrm{~kg}$ chopped sugarcane based on the natural material. Next, the solutions were spread over the corresponding sugarcane piles, and the material was carefully homogenised. Samples of sugarcane were removed for subsequent analysis after $0,24,48,72$, and $96 \mathrm{~h}$ of treatment with the alkali. Microprocessed quicklime was used as the calcium oxide source; according to the manufacturer, the quicklime contained $94.1 \% \mathrm{CaO}$ and $0.5 \% \mathrm{MgO}$.

Samples were removed at the reported times and sent to the animal nutrition laboratory of the Unesp, Jaboticabal-SP, for chemical analysis. A sample was removed, weighed, and dried in a forced-air oven at $55^{\circ} \mathrm{C}$ until reaching a constant weight. After drying, the samples were pulverised in a Wiley mill equipped with a 1-mm sieve.

The samples were analysed for mineral matter $(\mathrm{MM})$, crude protein $(\mathrm{CP})$, and ether extract (EE), which were determined according to the methods described by the Association of Official Agricultural Chemists (AOAC, 2000). The neutral-detergent fibre (NDF) and acid-detergent fibre (ADF) were 
also analysed as per Van Soest, Robertson and Lewis (1991).

To determine the lignin (LIG) content, 72\% sulphuric acid was used (VAN SOEST, 1994). The quantity of cellulose (CEL) was calculated based on the difference between the ADF and LIG. The total carbohydrates (TC) were obtained according to the following formula: $\mathrm{TC}=100-(\mathrm{CP}+\mathrm{EE}+$ $\mathrm{MM})$. The non-fibrous carbohydrates (NFC) were determined by subtracting the NDF corrected for ash and protein content (NDFap) from the TC (SNIFFEN et al., 1992).

In the in vitro digestibility assay, the Daisy II $A N K O M \circledR$ rumen fermenter methodology was used as described by Holden (1999). A crossbred Holstein $\times$ Zebu bovine was used as the rumen fluid donor; this animal remained in a stall containing a feeding trough and a drinking trough for an adaptation period of 15 days. During the experimental period, the donor animal received a diet containing $20 \mathrm{~kg}$ of sugarcane hydrolysed with $0.5 \%$ calcium oxide with $24 \mathrm{~h}$ of air exposure and $3 \mathrm{~kg}$ of concentrate containing soybean meal, ground corn, and a mineral mixture.

The rumen content was collected manually prior to the first meal on the morning of the 16th day after the onset of adaptation. The rumen content was properly stored in a Thermos ${ }^{\circledR}$ bottle preheated to $39^{\circ} \mathrm{C}$. The rumen content was subsequently taken to the animal nutrition laboratory, where it was filtered through cotton fabric using manual pressure.

The content of the jugs was incubated for $48 \mathrm{~h}$. After adding $8 \mathrm{~g}$ pepsin and $40 \mathrm{~mL}$ hydrochloric acid, the content of the jugs was incubated for an additional $24 \mathrm{~h}$, for a total of $72 \mathrm{~h}$ of incubation. After incubation, the jugs were opened and drained. The bags were removed and placed in an oven at $55^{\circ} \mathrm{C}$ until reaching the constant weight required for the subsequent determination of the in vitro digestible dry matter (IVDMD) coefficients (TILLEY; TERRY, 1963).
The coefficients for the in vitro digestibility of the neutral-detergent fibre (IVDNDF) and the aciddetergent fibre (IVDADF), and the coefficient of the true in vitro true dry matter digestibility (IVTDMD) were also determined per Van Soest (1994).

A completely randomised, split-plot design was used with the doses of calcium oxide allocated to the plots $(0,0.5,1.0,1.5$, and $2.0 \%)$ and the air exposure times allocated to the subplots $(0,24$, 48, 72, and 96 h). Four repetitions were used per treatment. The in vitro digestibility data underwent the same experimental design, excluding the $2.0 \%$ calcium oxide dose in the plots and the 96-hour exposure time in the subplots. The number of doses and the times were reduced for the determination of the digestibility coefficients because of the results obtained by Domingues et al. (2011), who found that deterioration of the sugarcane caused the growth of fungi and yeast after $96 \mathrm{~h}$ of air exposure. Furthermore, the $2 \%$ dose was excluded because the results obtained with the $1.5 \%$ dose were similar. The data underwent analysis of variance and were laid out according to the treatment effects on the polynomial regression components, which were evaluated at a 5\% probability level using the F-test.

\section{Results}

No interaction was observed between the doses of calcium oxide and the air exposure time with regards to their effect on the studied variables. Increasing the calcium oxide dose negatively affected the NDF, ADF, LIG, TC, CEL, CP, and EE contents, and positively affected the NFC and MM contents.

A negative quadratic effect of the dose on the NDF was observed (Figure 1), and beginning at a dose of $1.0 \%$, the reductions in NDF content were more representative. For the $0,0.5,1.0,1.5$, and $2.0 \%$ doses of calcium oxide, the NDF contents were $50.84,45.10,39.98,36.90$, and $36.22 \%$, respectively. The doses for the inclusion of calcium 
oxide influenced the quantities of $\mathrm{ADF}$ and LIG reductions observed doses greater than 1.0\% (Figure in a decreasing linear fashion, with the greatest 1).

Figure 1. Neutral-detergent fibre (NDF), acid-detergent fibre (ADF) and lignin (LIG) contents in sugarcane as functions of the calcium oxide dose.

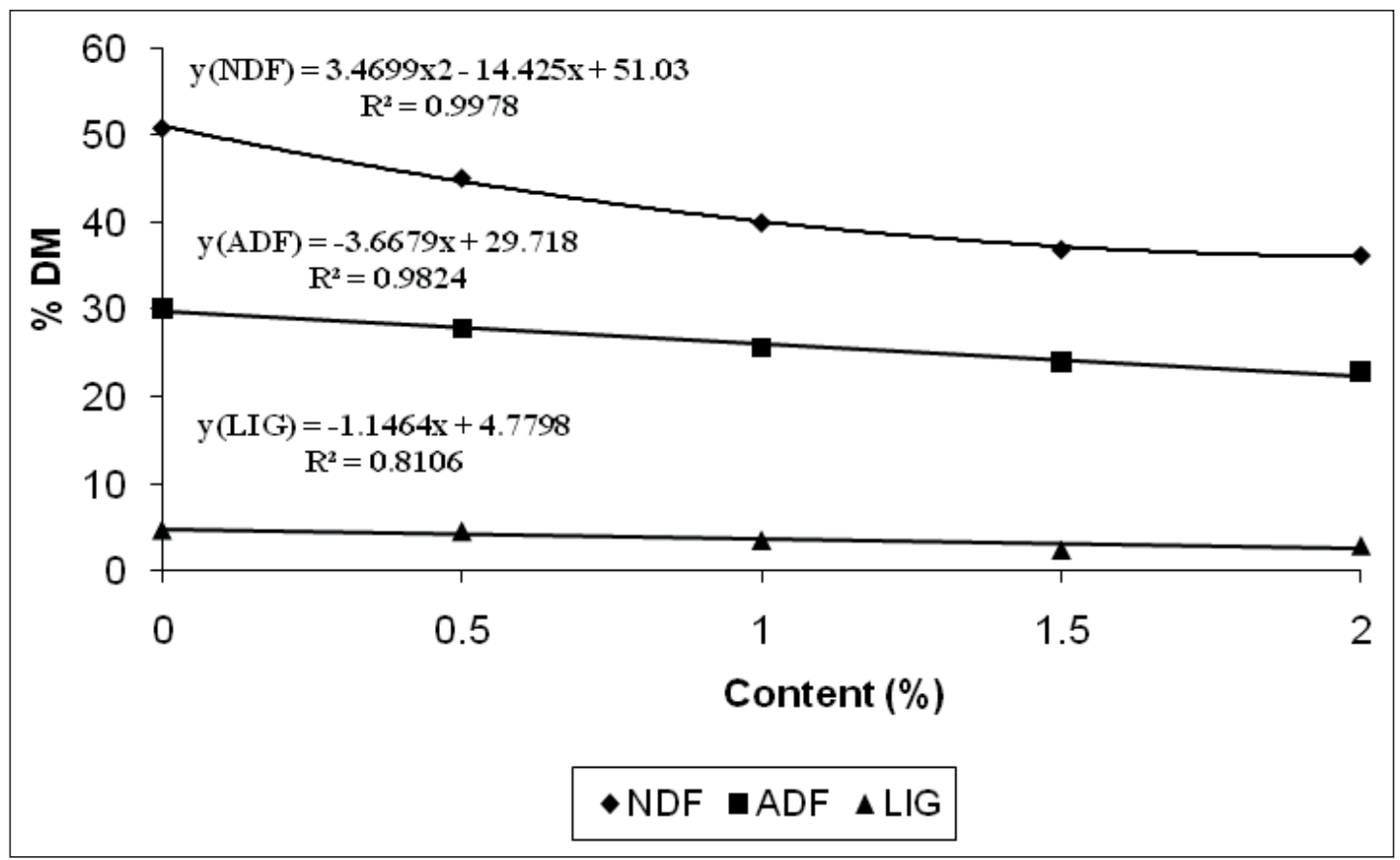

Source: Elaboration of the authors.

A quadratic effect was observed in the quantity of NFC.At doses of 1.0, 1.5, and 2.0\%, the NFC contents were $51.94,52.39$, and $51.99 \%$, respectively; These results were similar to one another and greater than the quantities corresponding to the doses of 0 and $0.5 \%$, which yielded NFC contents of 45.25 and $48.68 \%$, respectively (Figure 2). A quadratic effect was observed on the quantities of TC and CEL with the inclusion of calcium oxide; at a dose of $2 \%$, the lowest contents (86.32 and 20.1\%) were observed for the TC and CEL, respectively.

As the dose of calcium oxide increased, a quadratic effect was observed in the MM content. The highest MM content was observed at a dose of $2 \%$, at which a difference of $8.83 \%$ relative to the control treatment $(0 \%$ dose $)$ was observed. The CP and EE contents decreased linearly as a function of the dose, and the largest quantities were in the control treatment (Figure 3).

With regard to time, an increasing linear effect was found on the NDF, ADF, and LIG contents with increasing calcium oxide doses; the lowest contents of the NDF, ADF, and LIG (38.95, 24.02, and $3.29 \%$, respectively) were observed using no air exposure (0 time) (Figure 4).

The quantity of NFC decreased linearly with exposure to air; conversely, that of CEL increased in a linear fashion, similar to the other components of the fibrous portion of the sugarcane. The TC contents behaved in a quadratic manner (Figure 5). 
Figure 2. Cellulose (CEL), total carbohydrate (TC), and non-fibrous carbohydrate (NFC) contents in sugarcane as functions of the calcium oxide dose.

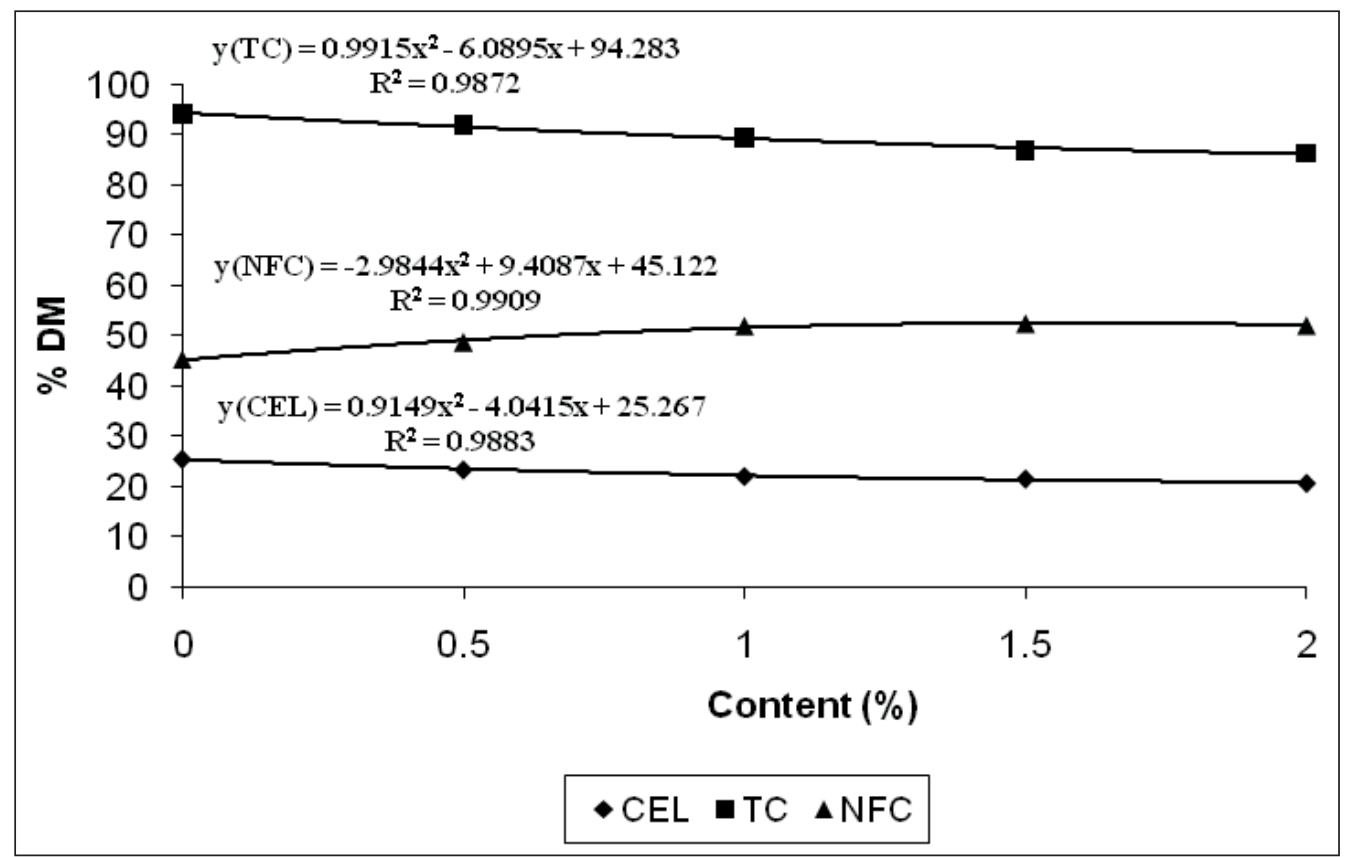

Source: Elaboration of the authors.

Figure 3. Crude protein (CP), ether extract (EE), and mineral matter (MM) contents in sugarcane as functions of the calcium oxide dose.

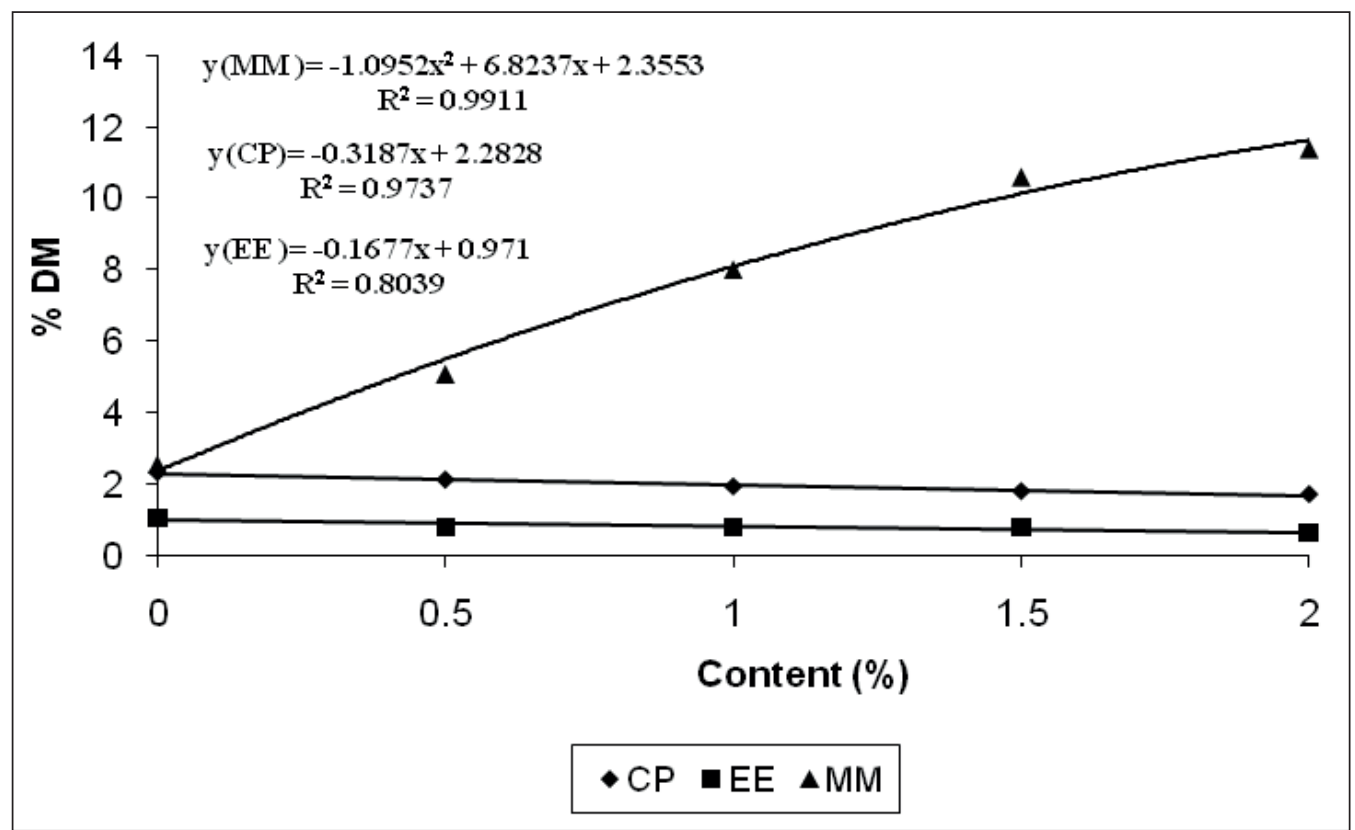

Source: Elaboration of the authors. 
The MM and CP increased linearly with air displayed negative quadratic behaviour, with the exposure time (Figure 6). The quantity of EE lowest quantity (1.1\%) observed at $24 \mathrm{~h}$ of air exposure.

Figure 4. Neutral-detergent fibre (NDF), acid-detergent fibre (ADF), and lignin (LIG) contents in sugarcane as functions of the air exposure time.

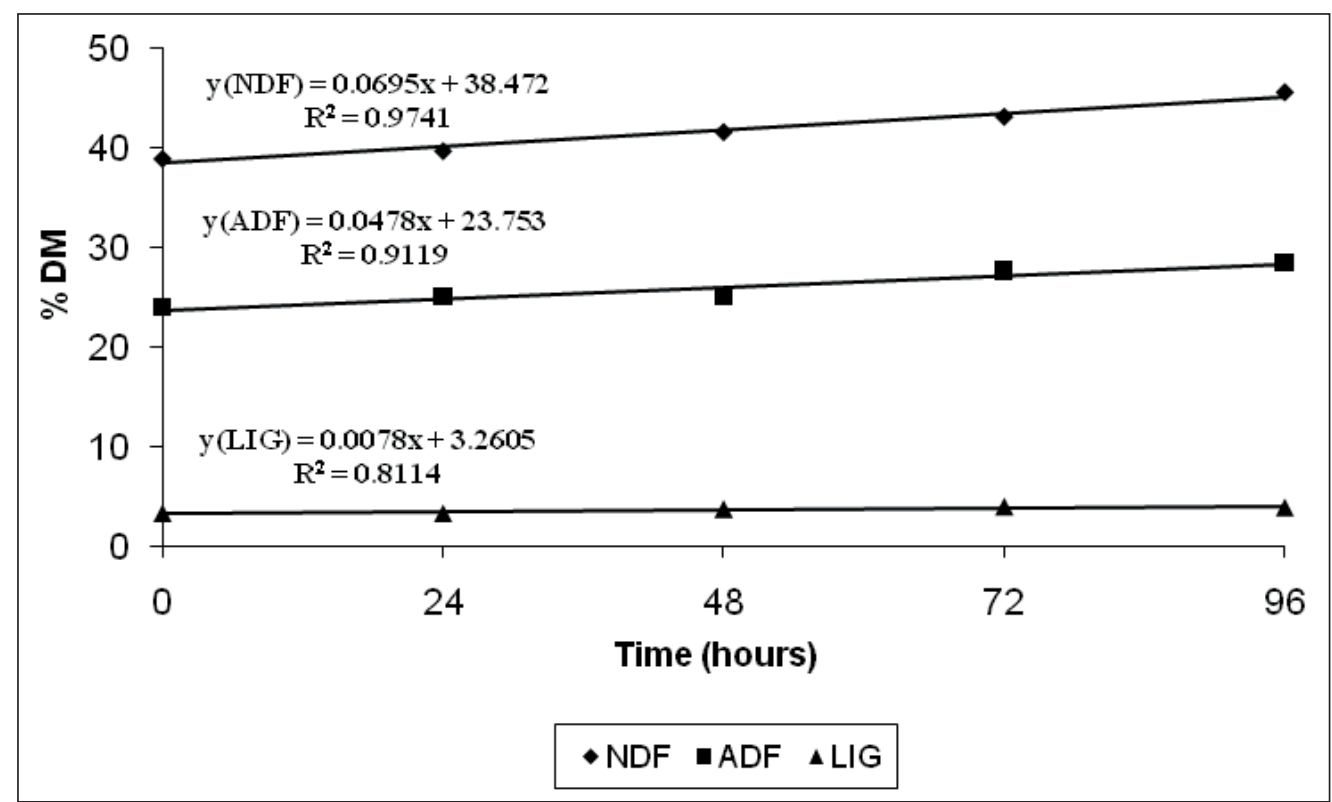

Source: Elaboration of the authors.

Figure 5. Cellulose (CEL), total carbohydrate (TC), and non-fibrous carbohydrate (NFC) contents in sugarcane as functions of air exposure time.

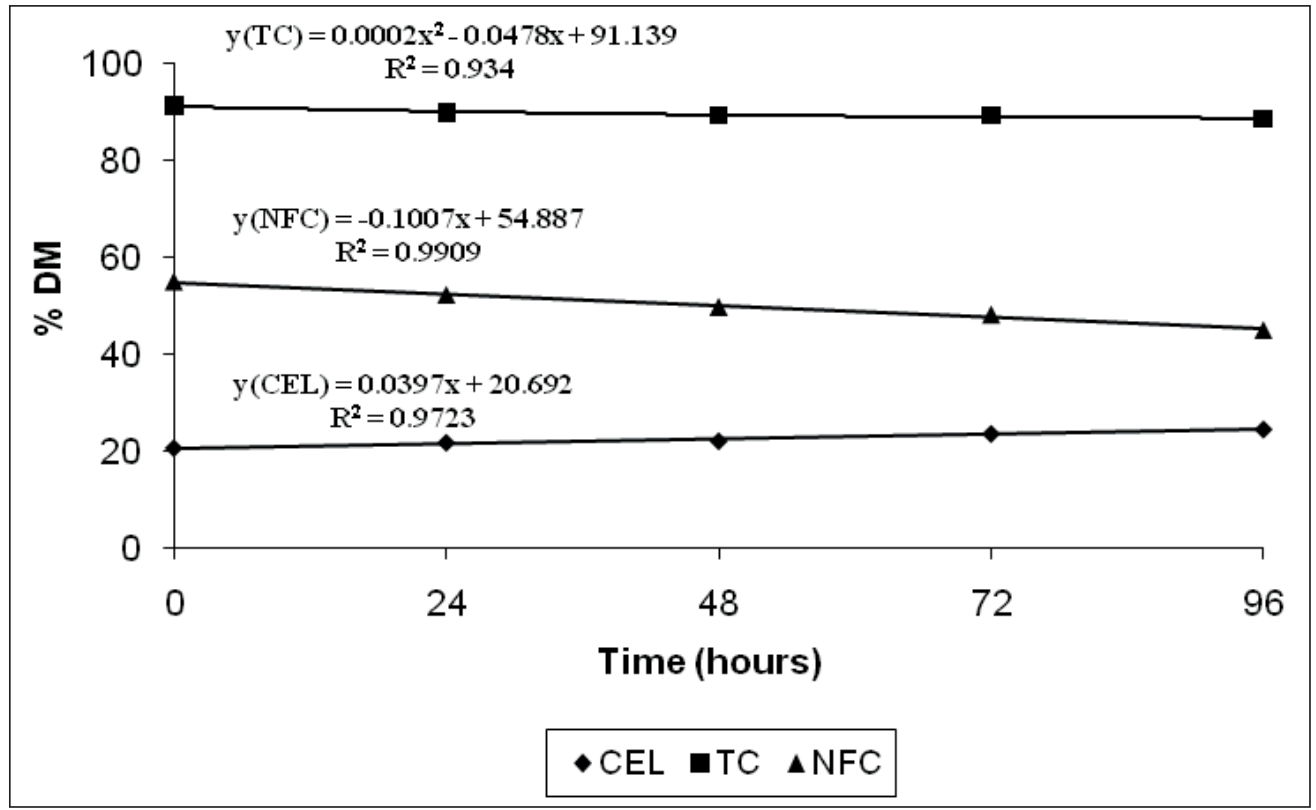

Source: Elaboration of the authors. 
An interaction was observed between the 0 to $24 \mathrm{~h}$ were similar, regardless of the calcium calcium oxide dose and the air exposure time for the oxide dose; at the longest exposure times (48 and IVDMD and IVDNDF coefficients only. Therefore, the IVDMD coefficients for air exposure times from $72 \mathrm{~h}$ ), the calcium oxide treatments yielded better IVDMD coefficients (Figure 7).

Figure 6. Crude protein $(\mathrm{CP})$, ether extract $(\mathrm{EE})$, and mineral matter $(\mathrm{MM})$ contents in sugarcane as functions of air exposure time.

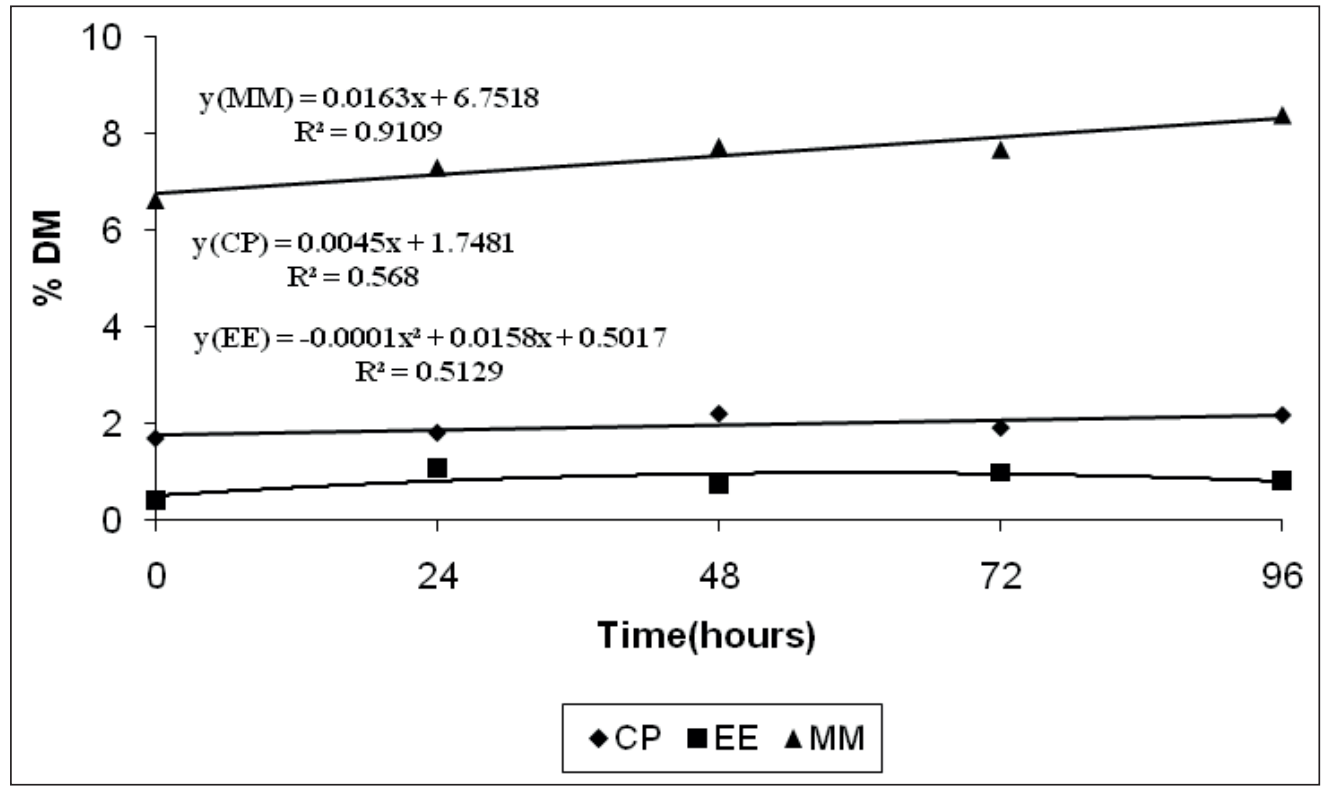

Source: Elaboration of the authors.

Figure 7. The interaction between calcium oxide dose and air exposure time for the in vitro dry matter digestibility (IVDMD) coefficients. $\mathrm{y}=69.9791-0.002833 \mathrm{t}^{2}+0.345841 \mathrm{dt}+0.008996 \mathrm{dt}^{2}+0.248576 \mathrm{~d}^{2} \mathrm{t}-0.005068 \mathrm{~d}^{2} \mathrm{t}^{2} ; \mathrm{R}^{2}=$ 0.72 .

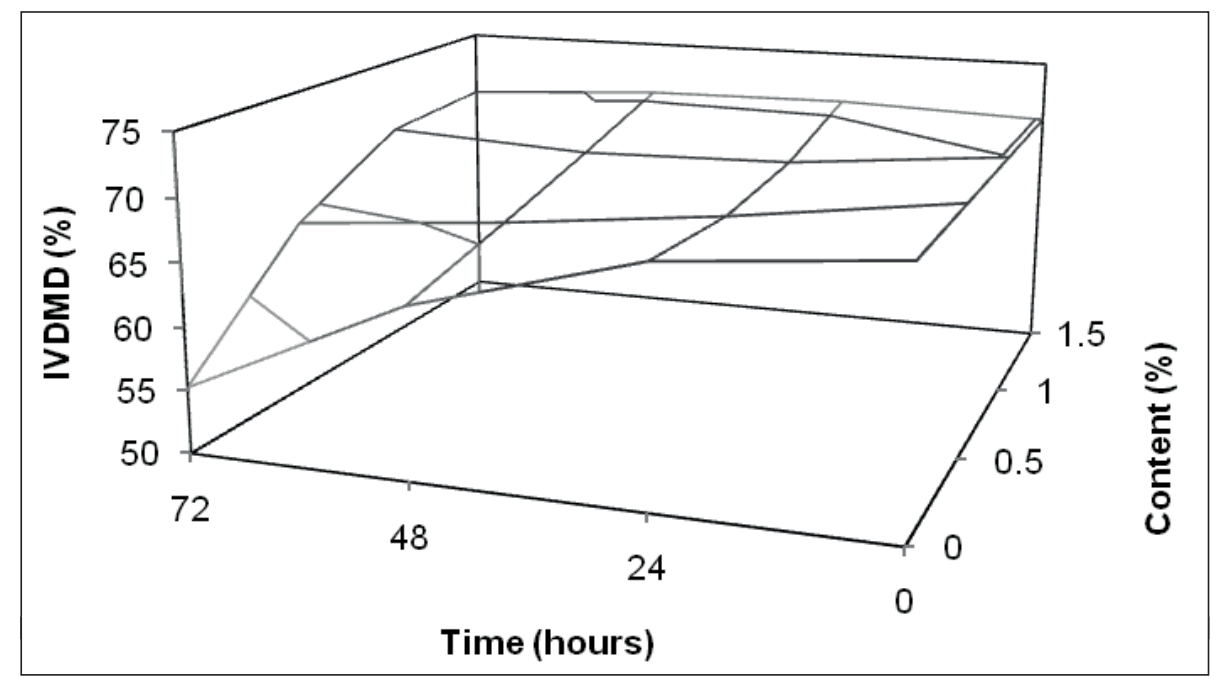

Source: Elaboration of the authors. 
The control treatment ( $0 \%$ dose) displayed larger coefficients for IVDNDF for all evaluated times. After the inclusion of calcium oxide, the IVDNDF coefficients decreased; however, better IVDNDF results were obtained for the calcium oxide treatments with increased air exposure times (Figure 8).

Figure 8. The interaction between the calcium oxide dose and air exposure time for the in vitro digestibility of neutraldetergent fibre (IVDNDF) coefficients. $\mathrm{y}=37.4014-4.194321 \mathrm{~d}+0.032853 \mathrm{dt} ; \mathrm{R}^{2}=0.15$.

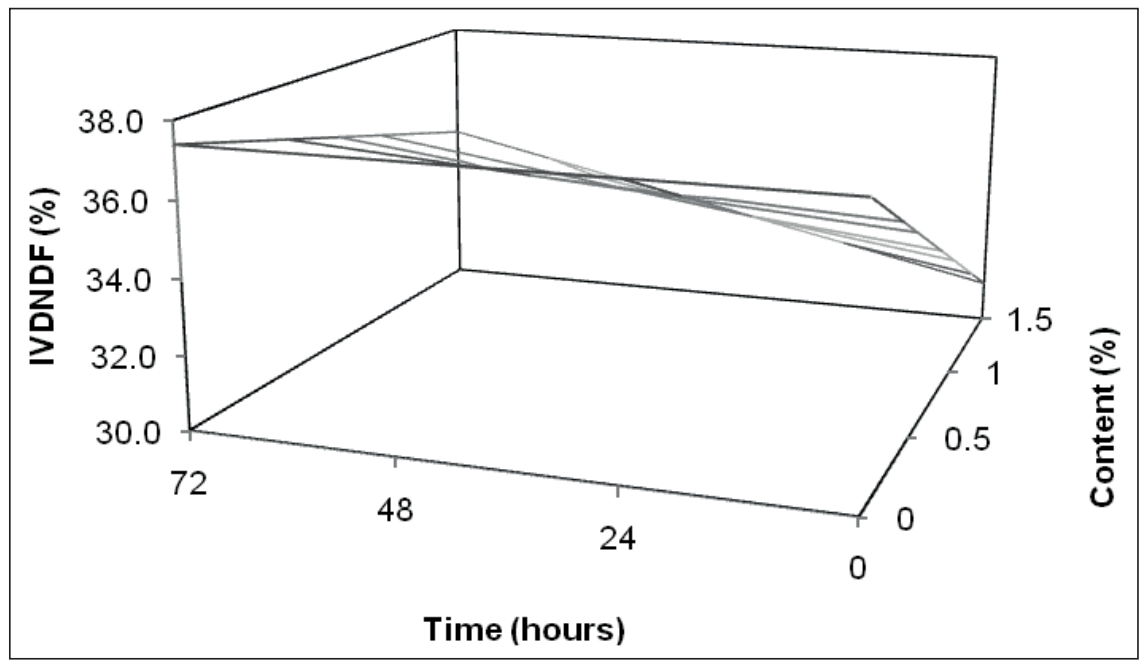

Source: Elaboration of the authors.

No interaction was detected between the calcium oxide dose and the air exposure time for the IVTDMD and IVDADF. No effects from the air exposure times were observed for IVDADF; effects were only observed for the calcium oxide dose. The inclusion of calcium oxide positively affected the IVTDMD coefficients and negatively affected the IVDADF coefficients.

The IVTDMD exhibited a quadratic effect; the results were $64.90,71.21,71.66$, and $70.79 \%$ for the 0 , $0.5,1.0$, and $1.5 \%$ calcium oxide doses, respectively. The IVTDMD coefficients for the treatments that contained calcium oxide were similar to yet greater than that of the zero-dose treatment (Figure 9).

Figure 9. The in vitro true dry matter digestibility (IVTDMD) coefficients of sugarcane as a function of calcium oxide dose.

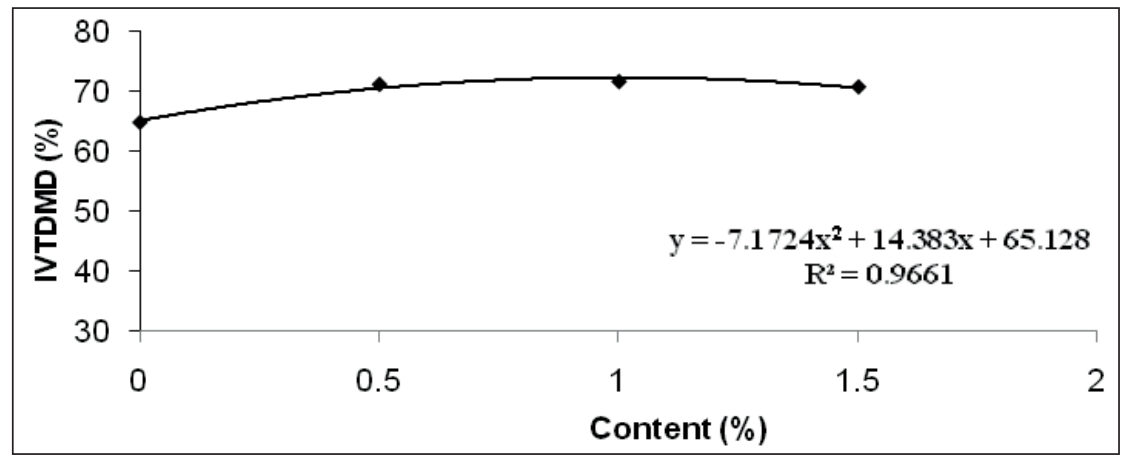

Source: Elaboration of the authors. 
The IVDADF coefficients decreased linearly with $\quad 26.99$, and $22.51 \%$ for the calcium oxide doses of 0 , calcium oxide dose; the values were 29.52, 26.80, 0.5, 1.0, and 1.5\%, respectively (Figure 10).

Figure 10. The in vitro digestibility of acid-detergent fibre (IVDADF) coefficients of sugarcane as a function of calcium oxide dose.

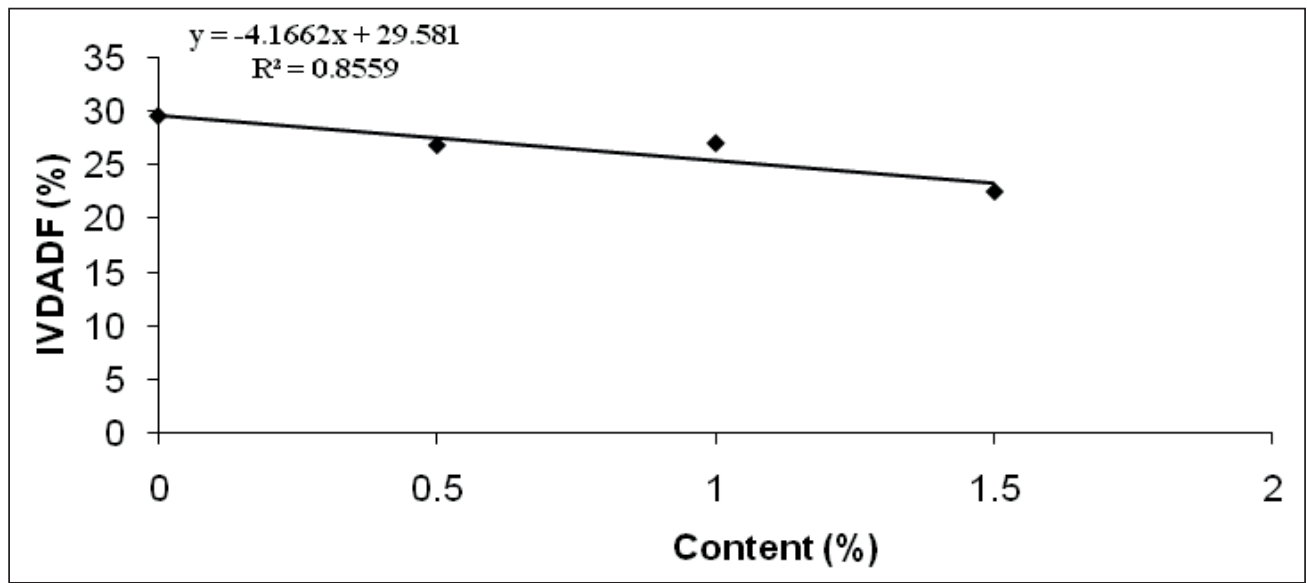

Source: Elaboration of the authors.

The IVTDMD coefficients decreased linearly with air exposure time (Figure 11). A significant reduction was observed during the first $24 \mathrm{~h}$, but this reduction did not continue for the remaining evaluated times. The coefficients were $72.80,69.26$, 68.90 , and $67.59 \%$ for the calcium oxide doses of 0 , $0.5,1.0$, and $1.5 \%$, respectively.

Figure 11. The in vitro true dry matter digestibility (IVTDMD) coefficients of sugarcane as a function of air exposure time.

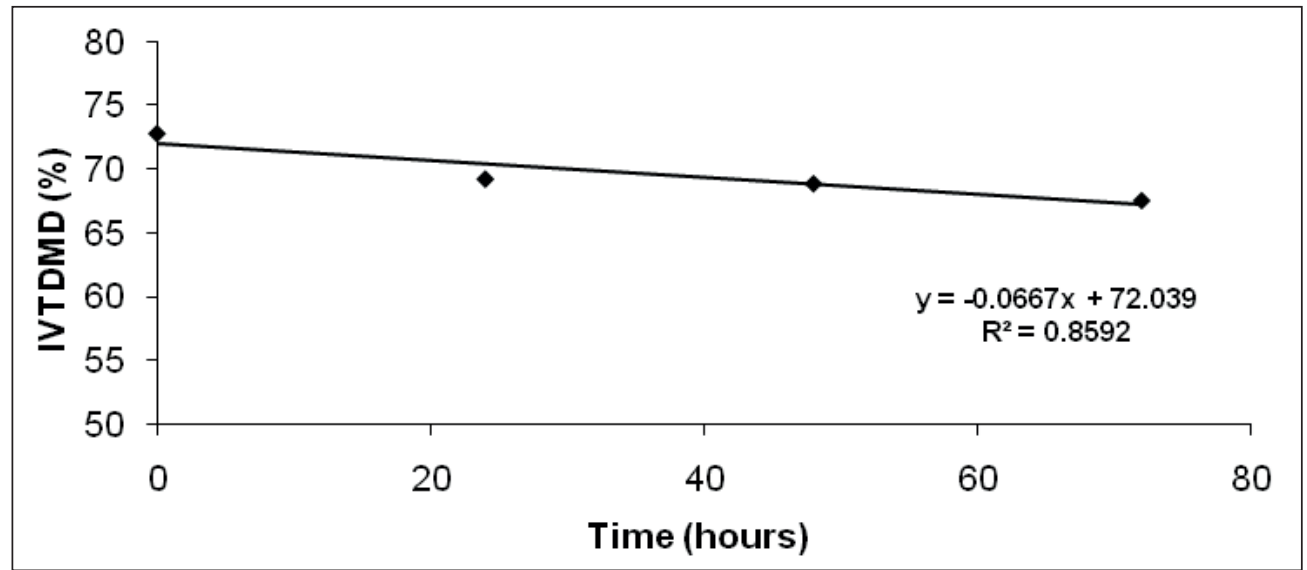

Source: Elaboration of the authors. 


\section{Discussion}

Calcium oxide was efficient in reducing the NDF content of sugarcane, confirming its hydrolysing action and corroborating the results obtained by Mota et al. (2010). According to Jackson (1977), this decrease occurs due to the partial solubility of the hemicellulose and the expansion of the cellulose.

The NDF is composed of cellulose, hemicellulose, and lignin (VAN SOEST, 1994); however, the reduction in the NDF content does not necessarily indicate that these compounds have been removed from the sugarcane after treatment with alkali. After hydrolysis, the bonds between the cellulose molecules (hydrogen bonds) and the bonds between the hemicellulose and lignin molecules (ester bonds) must have been broken, and during the extraction of the neutral detergent, these compounds were most likely removed by the neutral detergent during rinsing, thereby reducing the NDF content. Another hypothesis, is that the inclusion of greater amounts of lime can be provided a dilution effect on the NDF concentrations, since all are expressed in \% of DM.

The ADF and LIG contents decreased with calcium oxide doses greater than $1.0 \%$, indicating that lower doses were unable to act effectively on these variables; this inability to act at lower doses may be related to the greater rigidity of the ADF and LIG over that of the NDF. According to Wilkinson and Gonzalez (1978) and Klopfenstein (1977), the ADF and LIG contents are usually unaffected by alkali treatment. However, at greater calcium oxide doses, these compounds may be affected by the alkali as observed in the present study; this finding corroborates the study by Ribeiro et al. (2009), who observed that a high dose $(2.25 \%)$ of calcium oxide was also capable of reducing the ADF and LIG contents.

As with the other the fibrous fractions, the CEL content was reduced due to alkaline swelling of the cellulose in which the cellulose molecules expand, causing the hydrogen bonds to break (JACKSON, 1977). The evaluated variables that are related to the fibrous portion of the sugarcane (NDF, ADF, CEL, and LIG) decreased as a function of the calcium oxide dose, confirming that the hydrolysis by calcium oxide improved the quality of the fibrous fraction (KLOPFENSTEIN; KRAUS, 1972).

The positive effect of calcium oxide on the concentration of NFC was caused by the decrease in the NDF content. The decrease in the TC content with increased calcium oxide dose was primarily due to the increase in the MM content (the MM content was 4.45 times higher in the sugarcane hydrolysed with $2 \%$ calcium oxide compared to the control ( $0 \%$ calcium oxide).

The increase in the MM content with increasing calcium oxide dose was expected given the high MM content of the lime, which decisively contributed to the increase in this variable; these results are consistent with those of Rabelo et al. (2010).

The percentages of the fibrous fraction components (NDF, ADF, CEL, and LIG) increased with air exposure. This increase is merely a relative (percentage) increase related to the reduction in the quantity of NFC present and does not represent a volumetric increase in the NDF, ADF, CEL, or LIG. Because all nutrients are represented as a percentage of the DM content, the reduction of one component causes a corresponding increase in the others.

After exposure to air, the NFC content decreased linearly, corroborating the results obtained by Pina et al. (2009). This decrease is caused by the growth of spoilage microorganisms as described by Domingues et al. (2011) who evaluated the growth of yeast and fungi in hydrolysed sugarcane based on the calcium oxide dose and air exposure time. The abovementioned authors assert that yeast is the primary cause for the deterioration of the material and consumes the soluble carbohydrates present in the sugarcane, leading to increases in the NDF, ADF, CEL, and LIG contents. 
According to Mota et al. (2010), the increase in digestibility occurs due to the hydrolysing action of the calcium oxide and the resulting solubilisation of the fibrous fraction of the sugarcane (JACKSON, 1977). The present study found that sugarcane experiences an increase in the IVDMD when hydrolysed with calcium oxide. This increase in IVDMD may be attributed to chemical changes, given that the quantities of fibrous fraction components decrease when calcium oxide is added.

In addition to improving the IVDMD coefficients, the use of calcium oxide allowed this value to be maintained for up to $72 \mathrm{~h}$ of storage; this result was not observed in the control treatment $(0 \%$ calcium oxide), suggesting that the use of calcium oxide in the hydrolysis of sugarcane allows storage without decreasing the IVDMD. These results corroborate those obtained by Mota et al. (2010), who observed that the addition of calcium oxide, in addition to increasing the IVDMD coefficients, causes this value to be maintained for up to $72 \mathrm{~h}$ of air exposure.

The IVDNDF and IVDADF coefficients decreased when calcium oxide was added as previously observed by Oliveira et al. (2007). This addition likely acts first on the most easily degraded components of the fibrous portion. Some of these components are no longer present in the fibrous portion of the sugarcane after hydrolysis, causing the remaining portion to be less digestible. Another likely cause of the decrease in the IVDNDF and IVDADF coefficients is that the nutrients solubilised by the calcium oxide may be used by epiphytic microorganisms that proliferate during the storage period.

The calcium oxide exerted a positive effect, increasing the IVTDMD coefficient. The results obtained by treating the hydrolysed sugarcane were similar among the tested treatments and were greater than those obtained using the control treatment. During the first $24 \mathrm{~h}$, the IVTDMD was significantly reduced; this decrease did not continue for the rest of the evaluated times. The similarity among the results suggests that large doses of calcium oxide are not required; this result is useful given that treating sugarcane with broths containing high concentrations of calcium oxide is problematic due to the difficulty of dilution, especially when calcium oxide is used in the form of quicklime. In this context, the use of lower concentrations of calcium oxide is of great interest.

From a nutritional standpoint, the gains obtained by hydrolysing the sugarcane fibre are greater than the losses resulting from consumption of the soluble carbohydrates during periods of air exposure. In addition, the hydrolysis allows for the storage of sugarcane that has already disintegrated; thus, daily harvesting is not needed, thereby facilitating the transportation and logistics on the property farm.

\section{Conclusions}

Doses of 0.5 and $1.0 \%$ yielded results similar to those provided by larger doses; therefore, up 1,0\% doses are not necessary.

\section{References}

ASSOCIATION OF OFFICIAL ANALYTICAL CHEMISTS - AOAC. Official methods of analysis. $17^{\text {th }}$ ed. Gaithersburg, MD: AOAC International, 2000.

CARVALHO, G. G. P.; GARCIA, R.; PIRES, A. J. V.; SILVA, R. R.; SANTANA JUNIOR, H. A.; PINHEIRO, A. A.; MENDES, F. B. L.; RIBEIRO, L. S. O. Consumo e digestibilidade aparente em novilhas alimentadas com dietas contendo cana-de-açúcar tratada com óxido de cálcio. Revista Brasileira de Zootecnia, Viçosa, MG, v. 39, n. 12, p. 2703-2713, 2010.

CORRÊA, C. E. S.; PEREIRA, M. N.; OLIVEIRA, S. G.; RAMOS, M. H. Performance of Holstin cows fed sugarcane or corn silages of different grain textures. Scientia Agricola, Piracicaba, v. 60, n. 4, p. 221-229, 2003.

DOMINGUES, F. N.; OLIVEIRA, M. D. S.; SIQUEIRA, G. R.; ROTH, A. P. T. P.; SANTOS, J.; MOTA, D. A. Estabilidade aeróbia, $\mathrm{pH}$ e dinâmica de desenvolvimento de microorganismos da cana-de-açúcar in natura hidrolisada com cal virgem. Revista Brasileira de Zootecnia, Viçosa, MG, v. 40, n. 4, p. 715-719, 2011. 
HOLDEN, L. A. Comparison of methods of in vitro dry matter digestibility for ten feeds. Journal of Dairy Science, Champaign, v. 82, n. 8, p. 1791-1794, 1999.

JACKSON, M. G. Review article: the alkali treatments of straws. Animal Feed and Technology, Amsterdam, v. 2, n. 2, p. 105-130, 1977.

KLOPFENSTEIN, T. Chemical treatment of crop residues. Journal of Animal Science, Champaign, v. 46, n. 3, p. 841-848, 1977.

KLOPFENSTEIN, T.; KRAUS M. J. Chemical treatment of low quality roughages. Journal of Animal Science, Champaign, v. 35, n. 2, p. 418-422, 1972.

MOTA, D. A.; OLIVEIRA, M. D. S.; DOMINGUES, F. N.; MANZI, G. M.; FERREIRA, D. Z.; SANTOS, J. Hidrólise da cana-de-açúcar com cal virgem ou cal hidratada. Revista Brasileira de Zootecnia, Viçosa, MG, v. 39, n. 6, p. 1186-1190, 2010.

OLIVEIRA, M. D. S.; ANDRADE, A. T.; BARBOSA, J. C.; SILVA, T. M.; FERNANDES, A. R. M.; CALDEIRÃO, E.; CARBOLANTE, A. Digestibilidade da cana-de-açúcar hidrolisada, in natura e ensilada para bovinos. Ciência Animal Brasileira, Goiânia, v. 8, n. 1, p. $41-50,2007$

PINA, D. S.; TEDESCHI, L. O.; VALADARES FILHO, S. C.; AZEVEDO, J. A. G.; DETMANN, E.; ANDERSON, R. Influence of calcium oxide level and time of exposure to sugarcane on in vitro and in situ digestive kinetics. Animal Feed Science and Technology, Amsterdam, v. 153, n. 1, p. 101-112, 2009.

PINA, D. S.; VALADARES FILHO, S. C.; TEDESCHI, L. O.; BARBOSA, L. M.; AZEVEDO, J. A. G.; VALADARES, R. F. D.; SOUZA, N. K. P.; FONSECA, M. A. Níveis de inclusão e tempo de exposição da canade-açúcar ao óxido de cálcio sobre parâmetros digestivos e desempenho de novilhas nelore. Revista Brasileira de Zootecnia, Viçosa, MG, v. 40, n. 3, p. 648-656, 2011.
RABELO, C. H. S.; REZENDE, A. V.; NOGUEIRA, D. A.; RABELO, F. H. S.; ELIAS, R. F.; FARIA JÚNIOR, D. C. N. A. Composição químico-bromatológica e digestibilidade in vitro da matéria seca de cana-de-açúcar hidrolisada com cal virgem. Revista Brasileira Saúde e Produção Animal, Salvador, v. 11, n. 4, p. 1137-1149, 2010.

RIBEIRO, L. S. O.; PIRES, A. J. V.; PINHO, B. D.; CARVALHO, G. G. P.; FREIRE, M. A. L. Valor nutritivo da cana-de-açúcar hidrolisada com hidróxido de sódio ou óxido de cálcio. Arquivo Brasileiro de Medicina Veterinária e Zootecnia, Belo Horizonte, v. 61, n. 5, p. 1156-1164, 2009.

SNIFFEN, C. J.; O'CONNOR, J. D.; VAN SOEST, P. J.; FOX, D. G.; RUSSELL, J. B. A net carbohydrate and protein system for evaluating cattle diets: II. Carbohydrate and protein availability. Journal of Animal Science, Champaign, v. 70, n. 11, p. 3562-3577, 1992.

TILLEY, J. M. A.; TERRY, R. A. A two stage technique for the in vitro digestion of forage crops. Journal of the British Grassland Society, Oxford, v. 18, n. 2, p. 104-111, 1963.

VAN SOEST, P. J. Nutrition ecology of the ruminant. $2^{\text {th }}$ ed. Ithaca, NY: Cornell University Press, 1994. 476 p.

VAN SOEST, P. J.; ROBERTSON, J. B.; LEWIS, B. A. Symposium: carbohydrate methodology, metabolism and nutritional implications in dairy cattle. Journal of Dairy Science, Champaign, v. 74, n. 10, p. 3583-3597, 1991.

WILKINSON, J. M.; GONZALEZ SANTILLANA, R. Ensiled alkali treated straw. I. Effect of level and type of alkali on the composition and digestibility in vitro of ensiled barley straw. Animal Feed Science and Technology, Amsterdam, v. 3, n. 2, p. 117-132. 1978. 